University of Nebraska - Lincoln DigitalCommons@University of Nebraska - Lincoln

USGS Staff -- Published Research

US Geological Survey

2015

\title{
Another possible source of archeological maize found in Chaco Canyon, NM: The Tohatchi Flats area, NM, USA
}

Deanna Grimstead

The Ohio State University, grimstead.1@osu.edu

Sharon M. Buck

The Ohio State University

BradleyJ. Vierra

Statistical Research Inc., Albuquerque, NM

Larry V.Benson

University of Colorado at Boulder, great.basin666@gmail.com

Follow this and additional works at: http://digitalcommons.unl.edu/usgsstaffpub

Part of the Archaeological Anthropology Commons, and the Paleobiology Commons

Grimstead, Deanna; Buck, Sharon M.; Vierra, Bradley J.; and Benson, Larry V., "Another possible source of archeological maize found in Chaco Canyon, NM: The Tohatchi Flats area, NM, USA" (2015). USGS Staff -- Published Research. 891.

http://digitalcommons.unl.edu/usgsstaffpub/891

This Article is brought to you for free and open access by the US Geological Survey at DigitalCommons@University of Nebraska - Lincoln. It has been accepted for inclusion in USGS Staff -- Published Research by an authorized administrator of DigitalCommons@University of Nebraska - Lincoln. 


\title{
Another possible source of archeological maize found in Chaco Canyon, NM: The Tohatchi Flats area, NM, USA
}

\author{
Deanna N. Grimstead ${ }^{\mathrm{a}, *}$, Sharon M. Buck ${ }^{\mathrm{a}}$, Bradley J. Vierra ${ }^{\mathrm{b}}$, Larry V. Benson ${ }^{\mathrm{c}}$ \\ a Department of Anthropology, The Ohio State University, 4034 Smith Laboratory, 174 West 18th Avenue, Columbus, OH 43210-1106, USA \\ b Material Studies Program, Statistical Research Inc., 4425 Juan Tabo Blvd. NE, Suite 112, Albuquerque, NM 87111, USA \\ c Adjunct Curator of Anthropology, University of Colorado, Natural History Museum, 602 Pine St., Boulder, CO 80302, USA
}

\section{A R T I C L E I N F O}

\section{Article history:}

Received 12 April 2015

Received in revised form 1 June 2015

Accepted 2 June 2015

Available online $\mathrm{xxxx}$

\section{Keywords:}

Strontium isotopes

Maize sourcing

New Mexico

Chuska Valley

Chuska Slope

Chaco Canyon

\begin{abstract}
A B S T R A C T
Understanding the linkage and relationship between Chaco Canyon and its residents to surrounding communities has been a primary research question for several decades. This research has focused on identifying the Chacoan road systems, similar architectural designs, and the sourcing of economic and non-economic goods to outlier communities of origin. Extensive fieldwork has been completed to identify potential source regions of Chacoan corncobs, but the San Juan Basin and surrounding regions are vast and many potential agricultural features remain uninvestigated. One such region is the Tohatchi Flats, located near modern day Gallup, New Mexico. This paper uses ${ }^{87} \mathrm{Sr} /{ }^{86} \mathrm{Sr}$ ratios from synthetic soil waters, rabbit brush, and modern maize to investigate if this region is consistent with ratios obtained from archeological cobs from Chacoan great houses. Data results demonstrate that Tohatchi flats ${ }^{87} \mathrm{Sr} /{ }^{86} \mathrm{Sr}$ ratios are consistent with ratios from Pueblo Bonito cobs prior to AD 1130 but not after. Additionally, this study demonstrates that rabbit brush can serve as a modern proxy for maize, despite a small ${ }^{87} \mathrm{Sr} /{ }^{86} \mathrm{Sr}$ ratio offset, which this study concludes requires additional biogeochemical modeling and investigation to understand.
\end{abstract}

(c) 2015 Elsevier Ltd. All rights reserved.

\section{Introduction}

During the 11th and 12th centuries, Chaco Canyon lay at the center of a vast regional socio-political system, geographically centered in the immense San Juan Basin (Fig. 1). The Chacoan social network linked Puebloan communities living throughout this broad region. The importance of Chaco Canyon is indicated by the existence of 13 great houses, large multistory masonry structures that, for the most part, line the northern side of the Canyon. Pueblo Bonito, the most notable of these structures, may have reached five stories and contained upwards of 700 rooms (Neitzel, 2003; Stein et al., 2003; Windes, 2003). An extensive road system connected Chaco Canyon with outlier communities in the Basin (Kantner, 1997; Vivian, 1997a,b), perhaps symbolizing the linkage of those communities to the Canyon (Roney, 1992) or serving a cosmological or ritual function (Fowler and Stein, 1992; Marshall, 1997; Stein and Lekson, 1992). Outlier communities scattered across the San Juan Basin had architecture and features in common with Chaco, including great houses, plazas, and great kivas.

It has been proposed that Chacoan inhabitants were the ones whom actually built the Bonito style architecture in surrounding communities

\footnotetext{
* Corresponding author.

E-mail address: grimstead.1@osu.edu (D.N. Grimstead).
}

during the Bonito Phase (ca. AD 850-1150) even suggesting Chaco had a centralized system of control in the economy and religion (Vivian, 1990; Wilcox, 1993). On the other end of the spectrum Stein and Lekson (1992) argued that the region encompassing the Chacoan world was far too vast to be controlled by a centralized power structure. Rather they argued the Bonito style architecture symbolically linked the outlier communities to Chaco. A variety of models exist for explaining the relationship between Chaco and the outlier communities, each assigning varying degrees of importance to social hierarchies, ritual, trade, and identity (e.g. Lekson, 1999; Nelson, 1995; Saitta, 1997; Wills, 2000). More recently versions of a ritual-pilgrimage-feasting model have been favored (Malville and Malville, 2001; Renfrew, 2001), although a version of this model was originally proposed by Judge (1979).

In order to understand in more detail the relationship of the outlier and other communities to Chaco, scholars have attempted to unravel the trade and exchange relationships of certain materials between both entities. A key component of understanding the nature of the relationship Chaco had with the surrounding communities necessitates that we understand what material goods were coming into the Canyon, from what locations, and how these source regions varied throughout the socio-political history of Chaco. For example, the sources of ceramics (Toll et al., 1980; Toll and McKenna, 1997), minerals and ornaments (Mathien, 1997), lithics (Cameron, 1997, 2001), turquoise (Hull et al., 2014), timbers (Betancourt et al., 1986; Durand and Shelley, 1999; 


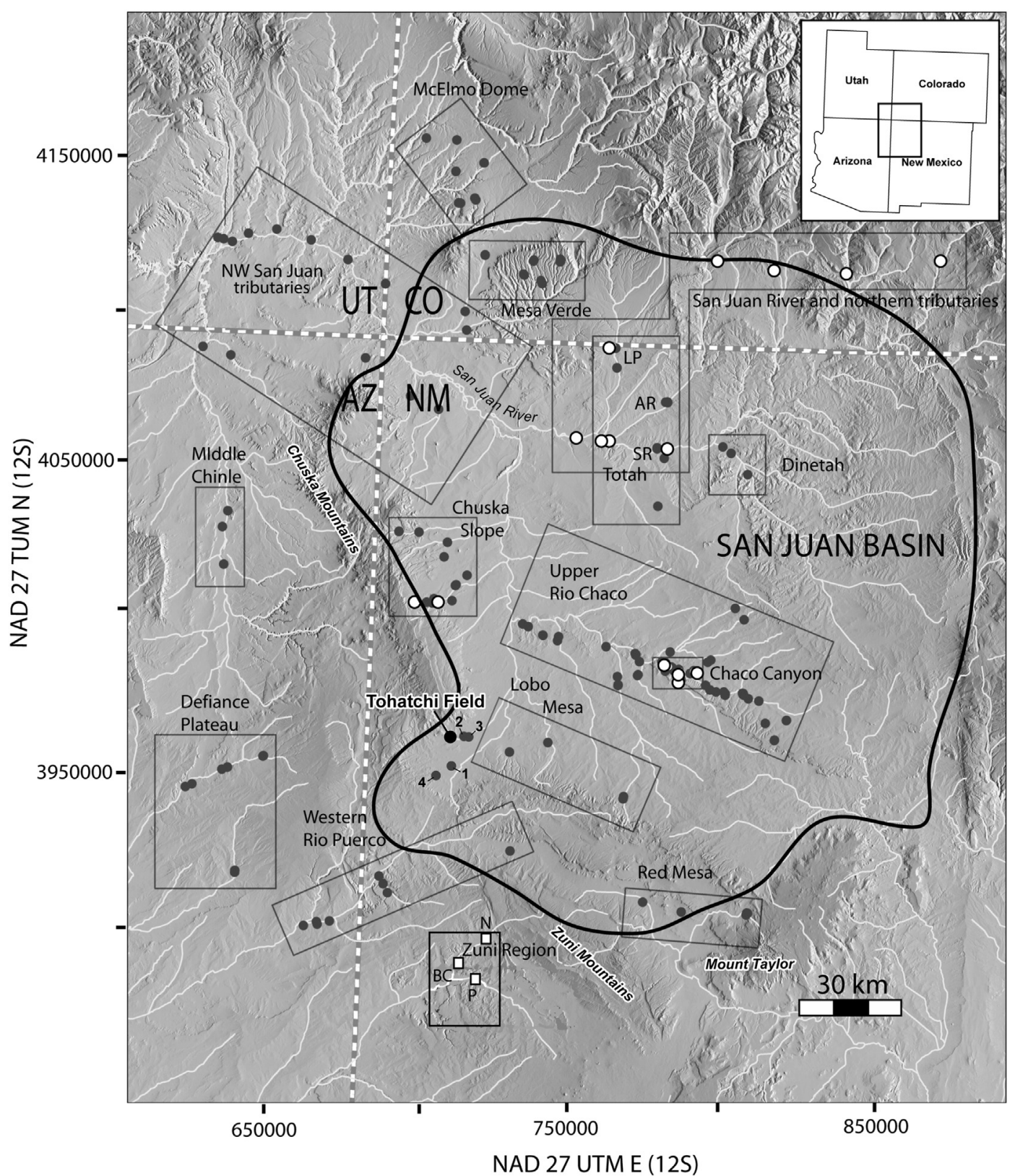

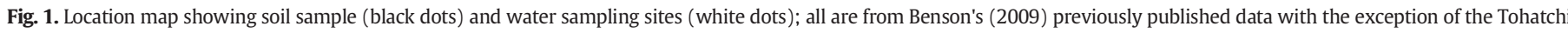

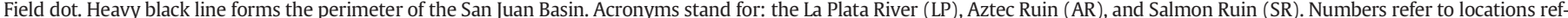

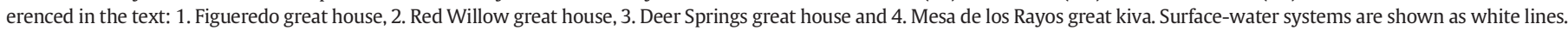
Rectangles bound labeled sampling regions listed in Table 2 from Benson et al. (2009). Coordinates referenced to NAD 27 datum.

Figure adapted from Benson et al. (2009) with permission.

English et al., 2001; Reynolds et al., 2005), animals (Grimstead et al., 2014, in press), and maize (Cordell et al., 2008; Benson, 2010, 2012; Benson et al., 2003, 2006, 2008, 2009) have all been investigated.

Maize has figured prominently in provenancing research, owing to its known ritual and dietary significance among past and present Southwestern cultures. This paper adds to the ever expanding geochemical regional data set used to understand possible source regions for Chacoan maize cobs (hereafter referred to as cobs). Unlike Benson et al. (2006, 2008), whom employed a synthetic soil water method for assessing the ${ }^{87} \mathrm{Sr} /{ }^{86} \mathrm{Sr}$ ratio (a ratio of strontium-87 to strontium-86 isotopes) regional variability, this paper favors the approach of growing Hopi Blue Corn (Zea mays L.) and collecting native plants with similar rooting depths to corn, such as rabbit brush (Ericameria nauseosa), within hypothesized source regions likely having a cultural connection to Chaco. By utilizing this methodology the ${ }^{87} \mathrm{Sr} /{ }^{86} \mathrm{Sr}$ ratio variability documented in agricultural plot samples will reflect the biopurification process conducted by plants as they metabolize bioavailable strontium from soil waters. The current study does not present baseline trace element paired ratio data for the modern materials, owing to the problems associated with using these ratios as a sourcing method on contaminated archeological cobs (see Benson, 2012).

While there is no consensus of the nature of neither the economic nor the socio-political system linking Chaco Canyon to its outlier communities, a number of sourceable materials found in Chaco Canyon appear to be derived from the Chuska Mountain region that lies $\sim 100 \mathrm{~km}$ west of the Canyon. These materials include: Narbona chert (Cameron, 1997), timbers used in the construction of Canyon great houses (English et al., 2001; Reynolds et al., 2005), large quantities of pottery (Cameron, 2001; Toll, 1991) and animals (Grimstead et al., in press). This study proposes that the southern Chuska Valley (Tohatchi Flats) 
was one potential source region for archeological cobs found in Chaco Canyon.

\subsection{Tohatchi Flats}

The southern Chuska Valley is situated along the Southwestern periphery of the Chuska Mountains. Although the area is commonly referred to as a valley, the topography of the region is actually characterized by a slope that descends from the mountains towards the nearby basin. When referring to this region we will use slope and valley interchangeably. Most of the valley is situated along the eastern slope of the Chuska Mountains, within their rain shadow; however, this is not true for the southern Chuska Valley, where the contour of the foothills shifts west, exposing the southern flanks of the mountains in the area of present day Tohatchi. Red Willow and Figueredo Washes flow down from these uplands, eventually emptying into the basin (Fig. 1). These settings have been the focus of human activity for many millennia. Indeed, Basketmaker II and III Period settlements, Chaco great houses and post-Chaco villages all were built along both of these washes.

Great house construction outside of Chaco Canyon began to increase by ca. AD 1000 and peaked by ca. AD 1130 (Kantner and Kintigh, 2006:182-183). It is during this time period that three Chaco great houses were built in the Tohatchi Flats area: Figueredo, Red Willow, and Deer Springs (Fig. 1). The Figueredo and Deer Springs great houses were situated within existing communities indicating that the local inhabitants, rather than outsiders from Chaco Canyon or elsewhere, may have constructed them. By contrast, the Red Willow great house was located between the Mesa de los Rayos great kiva and the Tohatchi Flats settlements suggesting a different relationship with Chaco Canyon. The linking of the Los Rayos great kiva and the Red Willow great house by a road segment seems to indicate both a symbolic and functional connection between the two communities and with Chaco Canyon (e.g. Gilpin, 2003; Gilpin et al., 1996; Kearns, 2000; Van Dyke, 2008:193-194; Vierra and Graves, 2014).

\section{Materials and methods}

\subsection{Field methods}

The growing location for the maize plot was selected based on an agricultural sustainability study conducted in the area (Homburg et al., 2014). Seeds were obtained from Native Seed Search, Tucson, AZ. One seed was planted approximately $30 \mathrm{~cm}$ from adjacent seeds at an

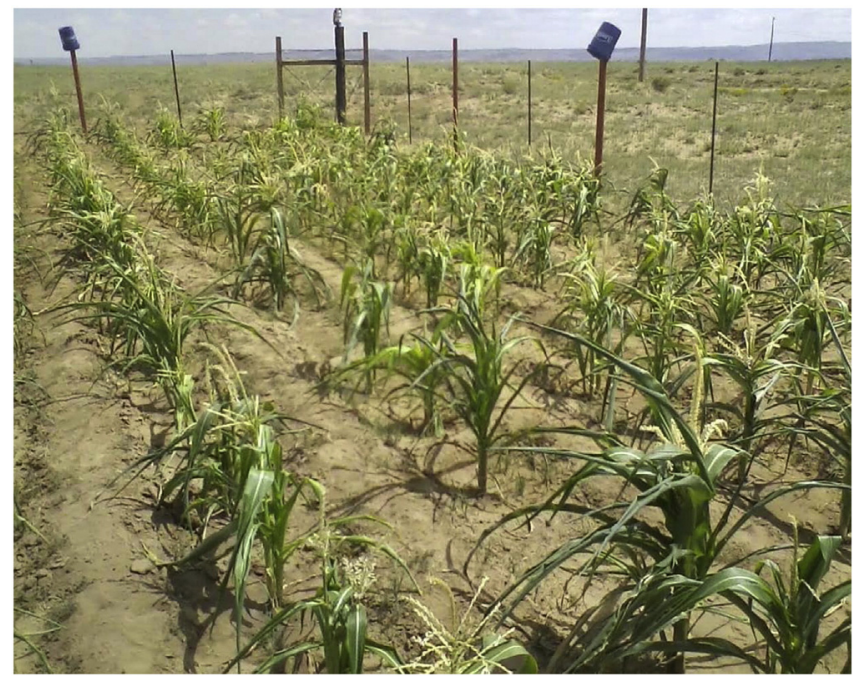

Fig. 2. A picture of the maize agricultural field used in this study. approximate depth of $10 \mathrm{~cm}$. A fence protected the plants from animals (Fig. 2). Initially it was hoped meteoric precipitation would provide all necessary water for the plants, but water had to be supplemented by local well water due to a drought. The depth of the well is unknown, but most in the region tend to be between 100 and $300 \mathrm{ft}$. deep. The well water was sampled once at the end of the study period (Sample 123603, Table 1). Ted Etsitty tended the field during the growing season (May to August) and estimated well water contributed $90 \%$ of the total water to the maize. Rabbit brush stalks were collected within an approximate $100 \mathrm{~m}$ radius of the corn plot and were not supplemented with well water. Soil samples were taken from the corn plot at depths of 15, 45 and $75 \mathrm{~cm}$, sample numbers 123600, 123601 and 123602 , respectively.

\subsection{Strontium isotope methods}

${ }^{87} \mathrm{Sr} /{ }^{86} \mathrm{Sr}$ ratios were obtained from water, soils, cobs, and rabbit brush stalk samples. $50 \mathrm{~mL}$ of the water sample was evaporated in a Teflon beaker then digested with equal parts of $47-51 \%$ trace metal grade hydrofluoric, $9 \mathrm{M}$ twice distilled nitric, and $6 \mathrm{M}$ twice distilled hydrochloric acid (bomb digestion). Synthetic soil waters were produced following the methodology of Benson et al. (2009). One gram of soil was homogenized with an agate mortar and pestle, and then placed in a $50 \mathrm{~mL}$ centrifuge tube with approximately $50 \mathrm{~mL}$ of twice distilled glacial $1 \mathrm{M}$ acetic acid. The sample was constantly agitated for a period of $24 \mathrm{~h}$. Once the period of agitation was complete the samples were

Table 1

${ }^{87} \mathrm{Sr} /{ }^{86} \mathrm{Sr}$ ratios from modern corn, rabbit brush, water and soil.

\begin{tabular}{|c|c|c|c|}
\hline Sample ID & ${ }^{87} \mathrm{Sr} /{ }^{86} \mathrm{Sr}^{*}$ & $2 \mathrm{SE}$ & Material \\
\hline 123570 & 0.709472 & 0.000008 & Maize \\
\hline $123571 \mathrm{~A}$ & 0.709368 & 0.000012 & Maize cob \\
\hline 123571B & 0.709370 & 0.000010 & Maize kernel \\
\hline 123572 & 0.709372 & 0.000016 & Maize \\
\hline 123573 & 0.709428 & 0.000018 & Maize \\
\hline 123574 & 0.709428 & 0.000011 & Maize \\
\hline 123575 & 0.709446 & 0.000011 & Maize \\
\hline 123576 & 0.709442 & 0.000014 & Maize \\
\hline 123577 & 0.709392 & 0.000012 & Maize \\
\hline 123578 & 0.709280 & 0.000014 & Maize \\
\hline 123579 & 0.709367 & 0.000012 & Maize \\
\hline 123580 & 0.709433 & 0.000011 & Maize \\
\hline 123581 & 0.709418 & 0.000014 & Maize \\
\hline 123582 & 0.709430 & 0.000018 & Maize \\
\hline 123583 & 0.709492 & 0.000011 & Maize \\
\hline 123584 & 0.709562 & 0.000008 & Maize \\
\hline 123585 & 0.709562 & 0.000010 & Maize \\
\hline 123586 & 0.709363 & 0.000010 & Maize \\
\hline 123587 & 0.709442 & 0.000029 & Maize \\
\hline 123588 & 0.709394 & 0.000011 & Maize \\
\hline 123589 & 0.709381 & 0.000006 & Maize \\
\hline 123590 & 0.709536 & 0.000008 & Rabbit brush \\
\hline 123591 & 0.709192 & 0.000012 & Rabbit brush \\
\hline 123592 & 0.709113 & 0.000010 & Rabbit brush \\
\hline 123593 & 0.709070 & 0.000007 & Rabbit brush \\
\hline 123594 & 0.709461 & 0.000006 & Rabbit brush \\
\hline 123595 & 0.709250 & 0.000007 & Rabbit brush \\
\hline 123596 & 0.709218 & 0.000012 & Rabbit brush \\
\hline 123597 & 0.709186 & 0.000008 & Rabbit brush \\
\hline 123598 & 0.709117 & 0.000019 & Rabbit brush \\
\hline 123599 & 0.709125 & 0.000008 & Rabbit brush \\
\hline 123600 & 0.709396 & 0.000010 & Soil leachate \\
\hline 123601 & 0.709429 & 0.000007 & Soil leachate \\
\hline 123602 & 0.709410 & 0.000009 & Soil leachate \\
\hline 123600 & 0.719473 & 0.000009 & Soil ${ }^{* *}$ \\
\hline 123601 & 0.715144 & 0.000014 & Soil $^{* *}$ \\
\hline 123602 & 0.714762 & 0.000020 & Soil ${ }^{* *}$ \\
\hline 123603 & 0.708525 & 0.000012 & Water \\
\hline
\end{tabular}


centrifuged and the liquid portion was extracted and evaporated prior to being dissolved in the bomb mixture followed by evaporation.

Approximately one gram of corn and rabbit brush samples were placed in crucibles and ashed at $450{ }^{\circ} \mathrm{C}$ for $12 \mathrm{~h}$. The furnace was heated up by $50{ }^{\circ} \mathrm{C}$ every $30 \mathrm{~min}$ until $450{ }^{\circ} \mathrm{C}$ was reached. After ashing the samples were left to cool for approximately $2-3 \mathrm{~h}$ or until crucibles were cool enough to handle. The samples were further powderized using an agate mortar and pestle, then dissolved in a sealed teflon beaker with the bomb mixture for approximately one week, after which the samples were evaporated.

All samples were brought up in $1 \mathrm{~mL}$ of $2 \mathrm{M}$ twice distilled hydrochloric acid before clean column chemistry (Bio-Rad resin). Each sample went through columns twice to ensure maximum removal of rubidium. ${ }^{87} \mathrm{Sr} /{ }^{86} \mathrm{Sr}$ ratios were measured using dynamic multicollection on a Finnigan MAT-261A thermal ionization mass spectrometer (TIMS) at the Radiogenic Isotope Laboratory in the School of Earth Sciences at The Ohio State University by the first and second authors. SRM-987 standards were analyzed with each sample batch (13 samples; two standards) for normalization, yielding an average ${ }^{87} \mathrm{Sr} /{ }^{86} \mathrm{Sr}$ ratio of $0.71024 \pm 0.00001(n=24)$. All ratios are corrected for mass fractionation by normalization to ${ }^{86} \mathrm{Sr} /{ }^{88} \mathrm{Sr}=0.1194$ and reported relative to the values for the SRM-987 standard.

\section{Geology and environment}

A rich background of prior research along with the diverse geological substrates of the region laid the groundwork for sourcing archeological cobs from Chaco Canyon, and this study adds another region consistent with ${ }^{87} \mathrm{Sr} /{ }^{86} \mathrm{Sr}$ ratios for the archeological cobs. Chaco Canyon (2073 m) lies in the middle of a broad basin that is surrounded by many mountain ranges with distinct geologies, including the Chuska Mountains (2982 m), the La Plata Mtns. (4035 m), the San Juan Mtns. (4361 m), the San Pedro Mtns. (3232 m), the Zuni Mtns. (2743 m), and Mt. Taylor (3444 m). The Tohatchi field site $(1940 \mathrm{~m})$ is located just south of the village of Tohatchi, which is situated approximately $75 \mathrm{~km}$ to the Southwest of Chaco Canyon (Fig. 1).

Chaco Canyon is situated within a desert-scrub grassland, with modern rainfall averaging $22.4 \mathrm{~cm} /$ year (Benson, 2011). The median value of frost-free days in the Canyon is 115 making it possible to grow maize about half the time (Benson, 2011), however, poor soil quality and low values of annual and summer precipitation likely resulted in low agricultural productivity during most of the Puebloan occupation of the Canyon (Benson, 2011). Thus, the poor agricultural potential of the Canyon has caused some to suggest that much of the food, specifically corn, was imported to the Canyon from part of the vast social network that surrounded the Canyon. The agricultural plots where the modern corn was grown and rabbit brush sampled is situated on a quaternary alluvial fan on a prominent hill located approximately $5 \mathrm{~km}$ south of the village of Tohatchi, New Mexico. Average rain fall from the Gallup Municipal Airport (KGUP), NM (The closest weather station) recorded an average annual rainfall of $26.70 \mathrm{~cm} /$ year from the period of July 1996 to December 2008 (Western Regional Climate Data Center, 2015).

Extensive previous maize sourcing research has produced baseline ${ }^{87} \mathrm{Sr} /{ }^{86} \mathrm{Sr}$ values from prehistoric agricultural fields throughout the region (Fig. 1; Benson et al., 2009). We build upon this previous work by adding data from agricultural fields near Tohatchi. ${ }^{87} \mathrm{Sr} /{ }^{86} \mathrm{Sr}$ analysis offers a direct method for identifying materials that were procured nonlocally (Bentley, 2006) and may rule out some potential source areas. In this study we analyzed ${ }^{87} \mathrm{Sr} /{ }^{86} \mathrm{Sr}$ ratios of plant, soil, and water sources to assess if the Tohatchi region has ${ }^{87} \mathrm{Sr} /{ }^{86} \mathrm{Sr}$ values consistent with Chacoan cobs.

${ }^{87} \mathrm{Sr} /{ }^{86} \mathrm{Sr}$ ratios are useful as a sourcing tool because the ratios are time- and rock-type dependent. That is, rocks of various ages have unique ${ }^{87} \mathrm{Sr} /{ }^{86} \mathrm{Sr}$ ratios due to the radiogenic decay of ${ }^{87} \mathrm{Rb}$ to ${ }^{87} \mathrm{Sr}$ and the initial ratio of ${ }^{87} \mathrm{Sr} /{ }^{86} \mathrm{Sr}$ ratio at the time of mineral formation. Airborne dust does contribute to the local measured soil ratios, which can contribute significant quantities of non-local strontium, particularly in arid regions (Graustein and Armstrong, 1983; Naiman and Quade, 2000; Reynolds et al., 2012). Strontium (Sr) is a stable alkaline earth metal that is incorporated into plants as they metabolize soluble bioavailable Sr from the groundwater in which they live (Burd, 1919; Eckert and Blincoe, 1970; Hart et al., 1932; Hurst and Davis, 1981; Sillen and Kavanagh, 1982). The ratios in vegetation reflect geographical variations in the ${ }^{87} \mathrm{Sr} /{ }^{86} \mathrm{Sr}$ of soil, dust, and water, because plants metabolize local bedrock and dust derived strontium from the soil and groundwater in which they live (Capo et al., 1998). It needs to be emphasized that plants do not directly metabolize Sr from soils, rather they metabolize bioavailable $\mathrm{Sr}$ from waters that have dissolved weakly bonded $\mathrm{Sr}$ from soils. Because there is no biological fractionation of the ${ }^{87} \mathrm{Sr} /{ }^{86} \mathrm{Sr}$ ratios, plants chemically reflect the ${ }^{87} \mathrm{Sr} /{ }^{86} \mathrm{Sr}$ ratio of soil waters.

\section{Results}

Modern corn ${ }^{87} \mathrm{Sr} /{ }^{86} \mathrm{Sr}_{\text {plant }}$ values ranged between 0.70956 and .70928 (mean $=0.70942$, standard deviation $(\mathrm{SD}) \pm 0.00007$ ), rabbit brush ranges from 0.70953 to 0.70907 (mean $=0.7092$, SD $=$ 0.0002 ), soil leachate values are 0.709396 (15 cm depth), 0.709429 (45 cm depth) and 0.709429 (75 cm depth), and the irrigation water is 0.708515 (Table 1). On average corn is shifted towards more radiogenic values when compared to rabbit brush (Table 1, Fig. 3; Wilcoxon/Kruskal-Wallis Tests of ranked sums: (SD of ranked sums) $=91$, Z-score $(Z)=-2.896, p=0.0038$ ). The soil leachates are all the same value when two standard errors (SE) are considered. The larger SD of rabbit brush compared to maize is to be expected, as maize was sampled from a small garden plot (Fig. 2), while rabbit brush was sampled randomly from within $100 \mathrm{~m}$ of the maize garden plots. These results are consistent with previous modern samples from the Chuska slope (Benson et al., 2009).

As recognized by Benson (2012) increases in the number of potential agricultural plots sampled results in a greater number of source locations that are consistent with ${ }^{87} \mathrm{Sr} /{ }^{86} \mathrm{Sr}$ ratios of archeological cobs. Eight of the archeological cobs originally analyzed by Benson et al. (2009) are consistent with ${ }^{87} \mathrm{Sr} /{ }^{86} \mathrm{Sr}$ ratios from the Tohatchi Flats in addition to the potential source regions originally identified by Benson

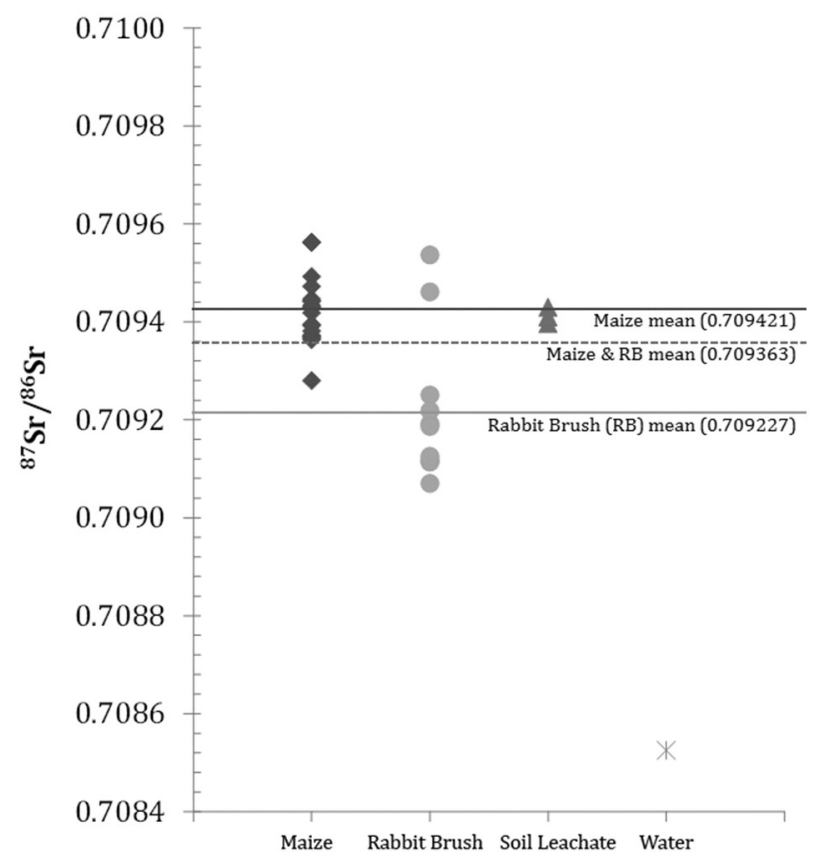

Fig. $3 .{ }^{87} \mathrm{Sr} /{ }^{86} \mathrm{Sr}$ plot of modern maize, rabbit brush, synthetic soil waters and the well water used for irrigation of the cob plot. 
Table 2

Non-diagenetically altered Chaco Canyon corn $\mathrm{cob}^{87} \mathrm{Sr} /{ }^{86} \mathrm{Sr}$ values; adapted from Benson (2009).

\begin{tabular}{|c|c|c|c|c|}
\hline Site no. & Provenance & Era & ${ }^{87} \mathrm{Sr} /{ }^{86} \mathrm{Sr}$ & $2 \mathrm{SE}$ \\
\hline \multicolumn{5}{|l|}{ Pueblo Bonito cobs } \\
\hline H10648 & Pueblo Bonito, room 170 & Pre-AD 1130 & 0.709892 & 0.000016 \\
\hline $\mathrm{H} 242 / 244 \mathrm{~A}^{*}$ & Pueblo Bonito, room 3 & Pre-AD 1130 & 0.709319 & 0.000016 \\
\hline $\mathrm{H} 242 / 244 \mathrm{~B}^{*}$ & Pueblo Bonito, room 3 & Pre-AD 1130 & 0.709475 & 0.000042 \\
\hline $\mathrm{H} 254 / 258 A^{*}$ & Pueblo Bonito, room 3 & Post-AD 1130 & 0.709394 & 0.000010 \\
\hline $\mathrm{H} 254 / 258 \mathrm{~B}^{*}$ & Pueblo Bonito, room 3 & Pre-AD 1130 & 0.709225 & 0.000018 \\
\hline H7673* & Pueblo Bonito, room 92 & Pre-AD 1130 & 0.709328 & 0.000011 \\
\hline \multicolumn{5}{|l|}{ Other Chaco Canyon cobs } \\
\hline CHCU2685-2 & Cliff face & Post-AD 1300 & 0.710082 & 0.000015 \\
\hline CHCU32288-1* & Chetro Ketl, room 92 & Post-AD 1130 & 0.709523 & 0.000014 \\
\hline CHCU32288-2* & Chetro Ketl, room 92 & Post-AD 1130 & 0.709350 & 0.000009 \\
\hline CHCU43684-1 & Gallo Cliff Dwelling & Post-AD 1130 & 0.710880 & 0.000014 \\
\hline CHCU43684-3 & Gallo Cliff Dwelling & Post-AD 1130 & 0.709638 & 0.000011 \\
\hline CHCU43684-5 & Gallo Cliff Dwelling & Post-AD 1130 & 0.709586 & 0.000015 \\
\hline CHCU43684-6* & Gallo Cliff Dwelling & Post-AD 1130 & 0.709412 & 0.000011 \\
\hline CHCU43684-8 & Gallo Cliff Dwelling & Post-AD 1130 & 0.709759 & 0.000011 \\
\hline CHCU43684-9 & Gallo Cliff Dwelling & Post-AD 1130 & 0.710010 & 0.000014 \\
\hline CHCU43684-10 & Gallo Cliff Dwelling & Post-AD 1130 & 0.709961 & 0.000014 \\
\hline CHCU43684-15 & Gallo Cliff Dwelling & Post-AD 1130 & 0.710143 & 0.000015 \\
\hline CHCU43684-16 & Gallo Cliff Dwelling & Post-AD 1130 & 0.710094 & 0.000013 \\
\hline Site \#1 Chaco E cob \#2 & 29 SJ 176, LA 40176 & Post-AD 1300 & 0.709839 & 0.000016 \\
\hline
\end{tabular}

Bold and asterisk indicates significance are cobs having ${ }^{87} \mathrm{Sr} /{ }^{86} \mathrm{Sr}$ values that overlap with Tohatchi.

(Table 2, Fig. 4), which included many of the side-valley tributary systems found between Chaco Canyon and the Chuska slope. Five of the six cobs from Pueblo Bonito have ${ }^{87} \mathrm{Sr} /{ }^{86} \mathrm{Sr}$ values that overlap with Tohatchi; four of which are pre-AD 1130 cobs and the other a post-AD 1130 cob. The three post-AD 1130 cobs from Chetro Ketl and Gallo Cliff Dwelling also overlap with ${ }^{87} \mathrm{Sr} /{ }^{86} \mathrm{Sr}$ ranges from Tohatchi. The remaining archeological cobs (One pre-AD 1130, eight post-AD 1130 and two post-AD 1300 cobs) have ${ }^{87} \mathrm{Sr} /{ }^{86} \mathrm{Sr}$ values that fall well outside the range for Tohatchi, and we can say with a high degree of certainty these cobs did not come from Tohatchi. Although the archeological sample sizes are small Tohatchi could have been a source region for several of the pre- and post- 1130 Chaco Canyon cobs, but not for the post-AD 1300 cobs.

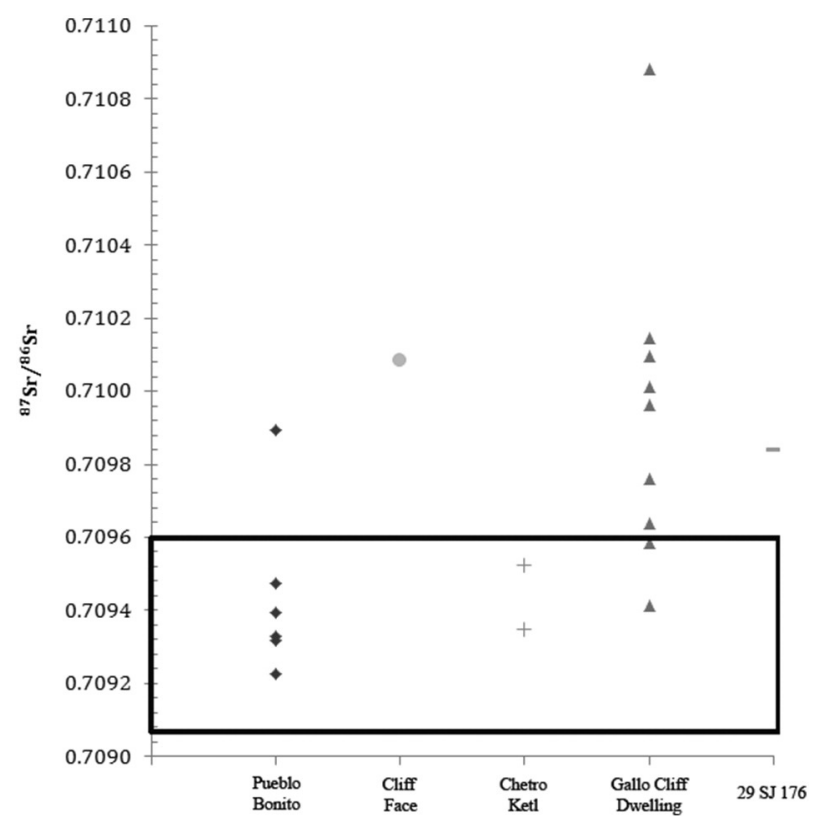

Fig. 4. Chaco Canyon $\mathrm{cob}^{87} \mathrm{Sr} /{ }^{86} \mathrm{Sr}$ ratios, from Benson (2009), plotted against the modern cob and rabbit brush data from the Tohatchi site (this study). The black box encompasses the minimum and maximum range of ${ }^{87} \mathrm{Sr} /{ }^{86} \mathrm{Sr}$ ratios documented in the modern cobs and rabbit brush.

\section{Discussion}

\subsection{Maize and rabbit brush offset}

Maize's mean ${ }^{87} \mathrm{Sr} /{ }^{86} \mathrm{Sr}_{\text {plant }}$ value is more radiogenic than rabbit brush, and the irrigation water is less than the mean for maize, suggesting that if the irrigation water contributed to the maize values, then it acted to shift the values more closely in line with the rabbit brush but probably not substantially. Soil leachate values overlap with both maize and rabbit brush minimum and maximum values, but they overlap very neatly with the corn values. It is unclear from the current data why we see such offsets between the maize and rabbit brush ratios, but four possible processes may be at work. Rabbit brush may have been exposed to soils with lower Sr isotope ratios than the maize. The soils were collected from within the maize plot and not the surrounding area where most of the rabbit brush was collected (100 m radius, See Section 2.1). Thus the soil samples may not be capturing the entire ${ }^{87} \mathrm{Sr} /{ }^{86} \mathrm{Sr}$ variability represented within the rabbit brush sampling area. It is possible that the different rooting depths or bunch depth of maize versus rabbit brush is responsible for the observed shift. That is, different depths, as evidenced by the complete digestion soils sampled from varying depths (see 2.1), have different bioavailable Sr mixtures resulting in a statistically different mean value for the two plants. It is suggestive that the $15 \mathrm{~cm}$ soil sample (Sample no. 123600) has the most radiogenic ratio and corn has approximately $75 \%$ of its root ball within $25 \mathrm{~cm}$ of the land surface. Further research into how rooting and bunch depths affect observed ${ }^{87} \mathrm{Sr} /{ }^{86} \mathrm{Sr}$ ratios in plants and soil profiles is forth coming by the first and fourth author, but is beyond the scope of this paper. It is also possible the mechanical movement of soil (tiling, planting, etc.) associated with maize farming combined with varying ${ }^{87} \mathrm{Sr} /{ }^{86} \mathrm{Sr}$ ratios from different depths exposed fresh mineral weathering surfaces in the soil matrix. This may serve to liberate more radiogenic $\mathrm{Sr}$ similar to the complete soil digestion ratios. Finally, the rabbit brush was not treated to remove any potential dust that had accumulated on the stalk. Research from near the study region has shown strontium derived from dust to range between 0.7087 and 0.7096 (Reynolds et al., 2012). The cob would have been protected from dust derived strontium thus explaining the offset. It also could be that all four possibilities are contributing to the more radiogenic maize values. As a discipline we need to extensively investigate this phenomenon, especially if we are to use proxies for maize. These observations 
also explicitly calls for modern sampling to focus on the plant that is to be sourced (in this case maize) if we are to most accurately recreate prehistoric biogeochemical environments. This of course can be prohibitive in the case of maize, which requires a farming field season, but it will be our best method until modeling of ${ }^{87} \mathrm{Sr} /{ }^{86} \mathrm{Sr}$ values from different plants, soil depths and soil spatial variation can be modeled accurately or measured precisely. All this being said variation of 0.0002 is very small for this region and does not change the results of the current sourcing study. Although there is an offset between maize and rabbit brush, this study demonstrates that rabbit brush can serve as an appropriate biogeochemical proxy for maize.

\subsection{Chacoan corn sources: pre- and post-AD 1130}

When combined with observations from Benson it appears that Chaco Canyon side valleys, side valleys of the Upper Rio Chaco, and the Chuska slope (including Tohatchi Flats) are potential candidates for maize fields prior to AD 1130. The entire side valley system of the Chaco Corridor and Slope could have been the source of Chaco's maize prior to AD 1130, but with emphasis on areas outside Chaco Canyon itself as only $\mathrm{Sr}$ isotope soil water samples from one of Chaco Canyon's side valleys (South Gap) overlapped with pre-AD 1130 archeological cob values from the Canyon. Only three of the post-AD 1130 cobs are consistent with values from Tohatchi, with the remainder having potential source regions within the Totah, Lobo Mesa, or a yet unsourced region. The post-AD 1300 Cliff Face cob does not overlap with any of the soils from this study or the Benson et al. (2009) source locations, but its radiogenic value is suggestive of a northern San Juan (up to 0.71399 ) origin given the high ${ }^{87} \mathrm{Sr} /{ }^{86} \mathrm{Sr}$ ratios associated with the San Juan and La Plata Mtns. and Northern San Juan Basin. An easterly or southerly origin for this cob cannot at present be ruled out due to the similarly radiogenic ratios associated with Cuba Mesa, Hosta Butte and the San Pedro Mtns. (Grimstead et al., in press).

It is perhaps not surprising that when we see the expansion and intensification of great house construction outside of Chaco Canyon (ca. AD 1000 and peaked by ca. AD 1130) (Kantner and Kintigh, 2006:182-183), in the Tohatchi flats area this includes: Figueredo, Red Willow, and Deer Springs (Fig. 1), most of the pre-AD 1130 cobs from Pueblo Bonito sourced to the Chacon side valleys, side valleys of the Upper Rio Chaco, and the Chuska slope, including Tohatchi Flats. By the abandonment of the Figueredo great house and elsewhere during the early Pueblo III period (AD 1100s) the primary source of Chacoan cobs shifts towards Northerly regions. Some cobs may have still been coming from the western and southwestern source regions, but if the observed sample is reflective of the broader pattern, then only small quantities continued to come from this region. During this time Tohatchi Flat sites became small and integrative with possible ties to these great houses. Great house architecture appears to have been replaced by new communal architectural forms, including the compound and bi-wall structures, during the late Pueblo III period (ca. AD 1200s) (Dykeman, 2003; Gilpin et al., 1996; Stein and Fowler, 1996). The replacement of Chacoan style great houses with these new forms of architecture and types of sites must be related to the collapse of the Chaco Phenomenon in this region and the kinds of post-Chaco reorganization documented for the Pueblo III period in adjacent areas such as the Cibola region (e.g., Kintigh, 1994; Schachner, 2008). Ties to the northern part of the Chuska Valley and Chaco Canyon had weakened by Pueblo III times with the Tohatchi area becoming more isolated. The remaining settlements were mostly abandoned by circa AD 1300 (Heilen and Leckman, 2014). The re-analysis of Chacoan cob sources presented herein suggests a strong tie between Chaco Canyon and the western and southwestern regions of the San Juan Basin prior to AD 1130, with this relationship weakening and shifting towards a more Northerly connection post-AD 1130. The same geographical and temporal pattern is observed in architectural timbers (English et al., 2001; Reynolds et al., 2005), while animals (Grimstead et al., in press), ceramics (Toll and
McKenna, 1997) and lithics (Cameron, 2001) also source to these regions.

\section{Conclusion}

Sourcing studies can provide a unique perspective on the social ties and networks that existed prehistorically, but to fully observe those connections extensive field sampling must occur in order to identify all the potential source regions. Perhaps the most useful application of isotopic sourcing studies is to exclude certain regions, rather than confirm a source region; especially considering as the number of geochemical sites investigated increases, so can the number of potential source regions for any given artifact. This phenomenon was demonstrated in the current study, as the geochemical investigations of prehistoric agricultural fields in the Tohatchi Flats region increased the number of potential source regions of cobs recovered from Chaco Canyon great houses by one. It should be emphasized, however, that this did not change the overall pattern of regional cob sources identified in previous studies. That is, pre-AD 1130 Chaco Canyon cobs were likely coming from the Chuska slope and nearby side valleys of the Upper Rio Chaco and South Gap in Chaco Canyon proper, while cobs postdating AD 1130 shifted towards more northerly origins.

Particularly in the regions to the south and east of Chaco, additional field investigations are required to identify potential source localities. Despite there being a systematic ${ }^{87} \mathrm{Sr} /{ }^{86} \mathrm{Sr}_{\text {plant }}$ offset between the rabbit brush and maize analyzed in this study, the data demonstrated that rabbit brush can serve as a proxy for maize, in conjunction with synthetic soil waters. Analyzing synthetic soil waters and plant samples in tandem allows the researcher to ensure the system is following expected biogeochemical principles. For cob sourcing studies the growing of maize in a potential agricultural plot is preferred, as this is the only way to mimic the prehistoric environment as closely as possible, but when this methodology is not feasible then this alternative strategy will suffice. Additional investigations are required to completely understand the offset between maize and rabbit brush, which is likely due to vertical and horizontal soil variation and plant rooting depths.

\section{Acknowledgments}

This research was funded by the New Mexico Department of Transportation (NMDOT), project number G5B16. We would like to thank Blake Roxlau (NMDOT) for supporting the project and Ted Ettsity for growing and tending to the corn. Work was conducted under a Navajo Nation Historic Preservation Department permit.

\section{References}

Benson, L.V., 2010. Who provided maize to Chaco Canyon after the mid-12th-century drought? J. Archaeol. Sci. 37, 621-629.

Benson, L.V., 2011. Factors controlling pre-Columbian and Early Historic maize productivity in the American southwest, part 2: the Chaco Halo, Mesa Verde, Pajarito Plateau/ Bandelier, and Zuni archaeological regions. J. Archaeol. Method Theory 18, 61-109.

Benson, L., 2012. Development and application of methods used to source prehistoric Southwestern maize: a review. J. Archaeol. Sci. 39, 791-807.

Benson, L., Cordell, L., Vincent, K., Taylor, H., Stein, J., Farmer, G.L., Futa, K., 2003. Ancient maize from Chacoan great houses: where was it grown? Proc. Natl. Acad. Sci. 100 13111-13115.

Benson, L., Stein, J., Taylor, H., Friedman, R., Windes, T.C., 2006. The agricultural productivity of Chaco Canyon and the source(s) of pre-Hispanic maize found in Pueblo Bonito. In: Staller, J.E., Tykot, R.H., Benz, B.F. (Eds.), Histories of Maize: Multidisciplinary Approaches to the Prehistory, Biogeography, Domestication, and Evolution of Maize. Elsevier/Academic Press, Amsterdam, pp. 289-314.

Benson, L.V., Taylor, H.E., Peterson, K.A., Shattuck, B.D., Ramontik, C.A., Stein, J.R., 2008 Development and evaluation of geochemical methods for the sourcing of archaeological maize. J. Archaeol. Sci. 35, 912-921.

Benson, L., Stein, J.R., Taylor, H.E., 2009. Possible sources of archaeological maize found in Chaco Canyon and Aztec Ruin, New Mexico. J. Archaeol. Sci. 36, 387-407.

Bentley, R.A., 2006. Strontium isotopes from the earth to the archaeological skeleton. J. Archaeol. Method Theory 13 (3), 135-187.

Betancourt, J.L., Dean, J.S., Hull, H., 1986. Prehistoric long-distance transport of construction beams, Chaco Canyon, New Mexico. Am. Antiq. 51, 370-375. 
Burd, J.S., 1919. Rate of absorption of soil constituents at successive stages of plant growth. J. Agric. Res. 18 (2), 51-71.

Cameron, C.M., 1997. The chipped stone of Chaco Canyon. In: Mathien, F.J. (Ed.), Ceramics, Lithics, and Ornaments Vol. II. Publications in Archaeology 18G, National Park Service, Santa Fe, NM, pp. 531-658.

Cameron, C.M., 2001. Pink chert, projectile points, and the Chacoan regional system. Am. Antiq. 66 (1), 79-101.

Capo, R.C., Stewart, B.W., Chadwick, O.A., 1998. Strontium isotopes as tracers of ecosystem processes: theory and methods. Geoderma 82, 197-225.

Cordell, L.S., Toll, H.W., Toll, M.S., Windes, T.C., 2008. Archaeological corn from Pueblo Bonito, Chaco Canyon, New Mexico: dates, contexts, sources. Am. Antiq. 73, 491-511.

Durand, S.R., Shelley, P.H., 1999. Trees, chemistry, and prehistory in the American Southwest. J. Archaeol. Sci. 26, 185-203.

Dykeman, D.D., 2003. Chuskan community in the Anasazi World. In: Reed, P.F. (Ed.), Anasazi Archaeology at the Millennium: Proceedings of the Sixth Occasional Anasaz Symposium. Center for Desert Archaeology, Tucson, Arizona, pp. 89-96.

Eckert Jr., R.E., Blincoe, C.R., 1970. Radioisotope uptake by selected range forage and weed species. J. Range Manag. 23 (5), 367-369.

English, N., Betancourt, J.L., Dean, J.S., Quade, J., 2001. Strontium isotopes reveal distant sources of architectural timber in Chaco Canyon, New Mexico. Proc. Natl. Acad. Sci. 98, 11891-11896.

Fowler, A.P., Stein, J.R., 1992. The Anasazi great house in space, time, and paradigm. In: Doyel, D.E. (Ed.), Anasazi Regional Organization and the Chaco System, Anthropological Papers, No. 5. Maxwell Museum of Anthropology, University of New Mexico, Albuquerque, pp. 102-122.

Gilpin, D., 2003. Chaco-era site clustering and the concept of communities. Kiva 69 171-205.

Gilpin, D., Dykeman, D.D., Reed, P.F., 1996. Anasazi community architecture in the Chuska Valley. Prepared for the New Mexico Archeological Council's Chuska Slope Outliers Tour, April 27 and 28, 1996. New Mexico Archaeological Council, Albuquerque.

Graustein, W.C., Armstrong, R.L., 1983. The use of ${ }^{87} \mathrm{Sr} /{ }^{86} \mathrm{Sr}$ to measure atmospheric transport into forested watershed. Science 219, 2890-292.

Grimstead, D.N., Reynolds, A.C., Hudson, A.M., Akins, N.J., Betancourt, J.L., 2014. Using strontium isotope population variance in turkey remains to evaluate domestication: a case study from Chaco Canyon, New Mexico, U.S.A. J. Archaeol. Method Theory (published on-line).

Grimstead, D.N., Quade, J., Stiner, M.C., 2015. Isotopic evidence for long-distance procurement and resource depletion, Chaco Canyon, New Mexico. Geoarchaeology (in press).

Hart, G.H., Guilbert, H.R., Goss, H. 1932. Seasonal changes in the chemical composition of range forage and their relation to nutrition of animals. University of California College of Agriculture, Bulletin 543. University of California Press, Berkeley.

Heilen, M., Leckman, P., 2014. Place, community and cultural landscape: Anasazi occupation of the Chuska Valley. In: Murrell, M., Vierra, B. (Eds.), Bridging the Basin: Land Use and Social History in the Southern Chuska Valley, Volume 4, Technical Report 14-20. Statistical Research Inc., Albuquerque, pp. 319-398.

Homburg, J.A., Heilen, M.P., Leckman, P.O., 2014. Agricultural soil quality and land use in the southern Chuska Valley. In: Murrell, M., Vierra, B. (Eds.), Bridging the Basin: Land Use and Social History in the Southern Chuska Valley, Volume 4, Technical Report 14-20. Statistical Research Inc., Albuquerque, pp. 253-290.

Hull, S., Fayek, M., Mathien, F.J., Roberts, H., 2014. Turquoise trade of the Ancestral Puebloan: Chaco and beyond. J. Archaeol. Sci. 45, 187-195.

Hurst, R.W., Davis, T.E., 1981. Strontium isotopes as tracers of airborne fly ash from coalfired power plants. Environ. Geol. 3, 363-367.

Judge, W.J., 1979. The development of a complex cultural ecosystem in the Chaco Basin, New Mexico. In: Linn, R.M. (Ed.), Proceedings of the First Conference on Scientific Research in the National Parks, 3. National Park Service Transactions and Proceedings Series 5, pp. 901-906.

Kantner, J., 1997. Ancient roads, modern mapping: evaluating Chaco Anasazi roadways using GIS technology. Expedition 39 (3), 49-61.

Kantner, J.W., Kintigh, K.W., 2006. The Chaco world. In: Lekson, S.H. (Ed.), The Archaeology of Chaco Canyon: An Eleventh-century Pueblo Regional Center. School of American Research Press, Santa Fe, New Mexico, pp. 153-188.

Kearns, T.M., 2000. LA 80951: Red Willow-Los Rayos Anasazi Road. In: Yost, S. (Ed.) Excavations in the Northern Tohatchi Flats. Pipeline Archaeology 1990-1993, The E Paso Natural Gas North System Expansion Project, New Mexico and Arizona, vol. V, book 3. Report No. WCRM(F)074. Western Cultural Resource Management, Farmington, New Mexico, pp. 7.1-7.11.

Kintigh, K.W., 1994. Chaco, communal architecture, and Cibolan aggregation. In: Wills, W.H., Leonard, R.D. (Eds.), The Ancient Southwestern Community: Models and Methods for the Study of Prehistoric Social Organization. University of New Mexico Press, Albuquerque, pp. 131-140.

Lekson, S.H., 1999. The Chaco meridian: centers of political power in the American southwest. Alta Mira Press, Walnut Creek, CA.
Malville, J.M., Malville, N.J., 2001. Pilgrimage and periodic festivals as processes of social integration in Chaco Canyon. Kiva 66, 327-344.

Marshall, M.P., 1997. The Chacoan roads - a cosmological interpretation. In: Morrow, B.H., Price, V.B. (Eds.), Anasazi Architecture and American Design. University of New Mexico Press, Albuquerque, pp. 62-74.

Mathien, F.J., 1997. Ornaments of the Chaco Anasazi. In: Mathien, F.J. (Ed.), Ceramics, Lithics, and Ornaments of Chaco Canyon, Publication 18G Volume III. National Park Service, Santa Fe, pp. 1119-1220.

Naiman, Z., Quade, J., 2000. Isotopic evidence for eolian recycling of pedogenic carbonate and variations in carbonate dust sources throughout the Southwest United States. Geochim. Cosmochim. Acta 64, 3099-3109.

Neitzel, Jill E. (Ed.), 2003. Pueblo Bonito: Center of the Chacoan World. Smithsonian Books, Washington, D.C

Nelson, B.A., 1995. Complexity, hierarchy, and scale: a controlled comparison between Chaco Canyon, New Mexico, and La Quemada, Zacatecas. Am. Antiq. 60, 597-618.

Renfrew, C., 2001. Production and consumption in a sacred economy: the material correlates of high devotional expression at Chaco Canyon. Am. Antiq. 66, 14-25.

Reynolds, A.C., Betancourt, J.L., Quade, J., Patchett, P.J., Dean, J.S., Stein, J., $2005 .{ }^{87} \mathrm{Sr} /{ }^{86} \mathrm{Sr}$ sourcing of ponderosa pine used in Anasazi great house construction at Chaco Canyon, New Mexico. J. Archaeol. Sci. 32, 1061-1075.

Reynolds, A.C., Quade, J., Betancourt, J.L., 2012. Strontium isotope and nutrient sourcing in a semi-arid woodland. Geoderma 189-190, 574-584.

Roney, J.R., 1992. Prehistoric roads and regional integration in the Chacoan system. In: Doyel, D.E. (Ed.), Anasazi Regional Organization and the Chaco System, Anthropological Papers, No. 5. Maxwell Museum of Anthropology, University of New Mexico, Albuquerque, pp. 123-131.

Saitta, D.J., 1997. Power, labor, and the dynamics of change in Chacoan political economy. Am. Antiq. 62, 7-26.

Schachner, G., 2008. Imagining communities in the Cibola Past. In: Varien, M.D. Potter, J.M. (Eds.), The Social Construction of Communities: Agency, Structure, and Identity in the Prehispanic Southwest. AltaMira Press, Lanham, Maryland, pp. 171-190.

Sillen, A., Kavanagh, A., 1982. Strontium and paleodietary research: a review. Yearb. Phys. Anthropol. 25, 67-90.

Stein, J.R., Fowler, A.P., 1996. Looking beyond Chaco in the San Juan Basin. In: Adler, M.A. (Ed.), The Prehistoric Pueblo World, A.D. 1100-1300. University of Arizona Press, Tucson, pp. 114-130.

Stein, J.R., Lekson, S.H., 1992. Anasazi ritual landscapes. In: Doyel, D.E. (Ed.), Anasazi Regional Organization and the Chaco System, Anthropological Papers, No. 5. Maxwell Museum of Anthropology, University of New Mexico, Albuquerque.

Stein, J.R., Ford, D., Friedman, R., 2003. Reconstructing Pueblo Bonito. In: Neitzel, N.E. (Ed.), Pueblo Bonito: Center of the Chacoan World. Smithsonian Institution Press, Washington, D.C., pp. 33-60.

Toll, H.W., 1991. Material distributions and exchange in the Chaco System. In: Crown, P.L, Judge, W.J. (Eds.), Chaco and Hohokam: Prehistoric Regional Systems in the American Southwest. School of American Research Press, Santa Fe, NM, pp. 77-107.

Toll, H.W., McKenna, P.J., 1997. Chaco ceramics. In: Mathien, F.J. (Ed.), Ceramics, Lithics, and Ornaments of Chaco Canyon: Analyses of Artifacts From the Chaco Project, 1971-1978. Archaeology 18G, National Park Service, Santa Fe, pp. 17-530.

Toll, H.W., Windes, T.C., McKenna, P.J., 1980. Late ceramic patterns in Chaco Canyon: the pregmatics of modeling ceramic exchange. In: Fry, R.S. (Ed.), Models and Methods in Regional Exchange, SAA Papers No. 1. Society for American Archaeology, Washington, D.C., pp. 95-117.

Van Dyke, R.M., 2008. The Chaco Experience: Landscape and Ideology at the Center Place. School for Advanced Research Press, Santa Fe, New Mexico.

Vierra, B.J., Graves, W.M., 2014. Movement, persistence and identity in the Southern Chuska Valley. In: Murrell, M., Vierra, B.J. (Eds.), Bridging the Basin: Land Use and Social History in the Southern Chuska Valley. Volume 4: Synthesis, Technical Report 14-20. Statistical Research Inc., Albuquerque, pp. 483-536.

Vivian, R.G., 1990. The Chacoan Prehistory of the San Juan Basin. Academic Press, New York

Vivian, R.G., 1997a. Chacoan roads: morphology. Kiva 63, 7-34.

Vivian, R.G., 1997b. Chacoan roads: function. Kiva 63, 35-67.

Western Regional Climate Center, 2015. Cooperative climatological data summaries Available online at. http://www.wrcc.dri.edu/climatedata/climsum/.

Wilcox, D.R., 1993. The evolution of the Chacoan polity. In: Malville, J.M., Matlock, G. (Eds.), The Chimney Rock Archaeological Symposium, General Technical Report No. RM-227. U.S.D.A. Forest Service, Fort Collins, CO, pp. 76-90.

Wills, W.H., 2000. Political leadership at Chaco Canyon, New Mexico, AD 1020-1140. In: Mills, B.J. (Ed.), Alternative Leadership Strategies in the Prehispanic Southwest. University of Arizona Press, Tucson, pp. 19-44.

Windes, T.C., 2003. This old house. In: Neitzel, J.E. (Ed.), Pueblo Bonito Center of a Puebloan World. Smithsonian Institution Press, Washington, D. C., pp. 14-32. 